e-issn: $2229-8568$

\title{
A Critical Examination of Land Cost Elements on Private Housing Development in Awori Land, Ogun State, Nigeria. A case of Ado/Odo-Ota LGA.
}

\author{
Orekan Atinuke Adebimpe ${ }^{1 *}$, Adeyemi Bamidele ${ }^{2}$ and Ubong John Ekott ${ }^{2}$ \\ ${ }^{1}$ Department of Estate Management, College of Environmental Sciences, Bells University of Technology, Ota, \\ Ogun State. \\ ${ }^{2}$ Estate Management Department, Faculty of Environmental Sciences, University of Lagos.
}

*Email: tinuorekan33@gmail.com

\begin{abstract}
This study examines the cost elements associated with land acquisition and development and the effect it has on public housing development using Awori land in Ado/Odo-Ota LGA in Ogun state, Nigeria, as a case study. To achieve this, a survey was administered to estate surveyors $\&$ valuers and officers of the Bureau of Lands and Survey who are involved in property developments. The findings revealed that land registration cost, lease cost, deeds of assignment were ranked as important. It is also found that there is also a significant relationship between land cost elements and rate of housing development. The study further revealed that there is a positive relationship between the land cost elements and the rate of housing development. In conclusion, this implies that an increase in one of the land cost elements will affect housing development.
\end{abstract}

Keywords: Awori, Housing Development, Land cost, Land Elements, Land Value.

\subsection{INTRODUCTION}

Land is put under the authority of the government to hold in trust for the purpose of administration. This therefore, means that for citizens to have access to land there must be, of necessity some form of acquisition of rights to own and use land. Land acquisition comes with certain cost elements such as land registration and titling, development fees, property/land tax, legal fees, survey fees and stamp duties etc.

A critical look at the cities in Nigeria today, reveals that they are confronted with a plethora of land related problems emanating from the use, allocation, distribution and ownership of land (Ogedengbe, 2004). These problems include inadequate housing, haphazard development, traffic congestion, inadequate infrastructural and social amenities, inefficient use of land, and inaccessibility of land among others. Unfortunately, most of the studies available both locally and internationally focused on housing challenges, demand and supply, housing development cost element, land policies, land use patterns and, planning schemes but do not focus on the cost attached to acquisition of land itself. Some of the studies undertaken include: Skaburskis and Tomalty (2000); EEA Technical Report (2010); Nichols, Oliner and Mulhall (2010); Ong (2013); Uwem (2014); Essaghah, Ighoruemufua, Ogedengbe (2004); \& Omatsone and Okoye (2013).

However, there seems to be none that have specifically considered the costs elements attached 
e-issn: $2229-8568$

to land. Skaburskis and Tomalty (2000), conducted a similar study on the impact of land taxes and development cost levies on city development in Toronto and Ottawa. They analysed the concept put forward by town planners, credit officers and developers in Toronto and Ottawa. They hinged on the opportunity of using property taxes and development cost charges to have effect on urban development and finance. Their study was quite useful except that it was limited to only property tax and development charges.

So far, studies on the subject revealed that in depth investigation of land cost element in housing delivery are very rare in Ado/Odo -Ota Local Government Area of Ogun State. There is thus, a great need for studies that can determine land cost and other related cost as they affect housing delivery. It is not enough to know that land costs elements exist, but much more importantly to ascertain empirically whether or not they have an overbearing effect on housing development and the importance of land cost element amongst other factors that affected private housing development. These are what the study seeks to achieve. As interesting as this study is, it did not consider the cost effect on private residential investment. This study shall be beneficial to private developers, government agencies, land tax officials, land administrators and the global community. This study attempts to examine the land cost elements on private housing delivery in "Awori land" using Ota, Atan, Iju and Agbara as the case study.

\subsection{LITERATURE REVIEW}

Land is a type of fixed asset which is not subjected to depreciation. The cost of land is based on its acquisition price. All costs associated with acquiring land and putting it to use are included in the cost of land. Land purchases mostly involves real estate commissions, legal fees, bank fees, title search fees and other similar ones. In other to get the land prepared for improvement, some other costs are also associated with it and these are cost to clear trees, removal of small hills and landscaping in some cases, old buildings might need to be demolished before the land can be put into use. Cost can be referred to as a major concept in economics. It is said to be a monetary expense incurred by organisations for variety of uses. According to the Institute of Cost and Work Accountants (ICWA) (2020), it is opined that cost implied measurement in the monetary terms of all the resources for the production of goods or for services rendered. In estimating the value of real estate, the cost method approach is used, this includes the underlying land cost with all cost associated with it and the depreciated value of the improvements.

Elements of cost comprises of materials, labour and expenses. Under materials, the cost in acquiring the materials or resources needed for converting product to a productive use is the material cost. Labour, one of the factors of production is needed in organisations to transform raw materials to finished goods or product. Labour cost has been identified as a main element of cost. The main aim of every organization is to earn maximum profit, and to achieve this, it depends on the management of its cost and total revenue. Various cost elements are further explained below in Figure 1. 


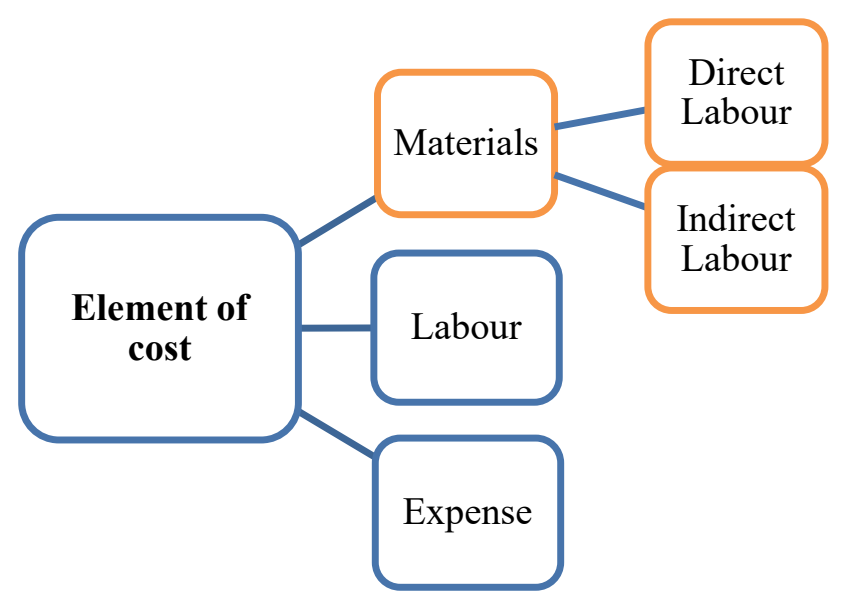

Figure 1: Cost elements in Land

Furthermore, the cost associated with land improvements are all expenses incurred in making development on land for use. This includes the cost of purchase price together with all cost related with the acquisition of the land and taxes paid. In the case of a built-up property that was just acquired, the cost of remodeling and cost involved in the repairs necessary to put it to use are part of the cost elements associated with the property. Other cost such as interest payments to finance the structure is also included in the cost of the assets; whereas it is classified as interest payment only after construction is completed and ready to be put into productive use (www.collateralmanagement.org).

In other part of the world mostly in developing countries, acquisition of land is always associated with certain costs which may include the cost of land, legal fees, zoning fees and survey costs etc. and some of these costs are regarded to as project cost by the property owners. According to the principle of accounting, it is known that cost of site preparation like grading and draining, demolishing the old structure may be considered ordinary but are cost of land improvement. Another question that readily comes to mind in accounting is that can the cost of land be separated from land improvement cost? As it is well acknowledged by a land economist; land does not depreciate in value but depreciation is always considered for the improvement on land in appraisal.

The magnitude of the cost component depends on the size, location and nature of the project. Land cost, Land Price and Land Value. Land cost is often used interchangeably with land value and land price, whereas they differ from one another. Land cost is like one of the most important parts of the cost of a new building. The value of land varies in accordance to market situation. Recently, the decrease in housing market will have a negative effect on land values. However, changes in land prices reflect the cyclical nature of the residential real estate market. Although the decrease in the real estate market which is similar to the period of 80's and 90's, was categorised as a result of a sharp drop in property values and on the extension of periods of minimal appreciation before prices recovered (Douglas, 2014). Intuitively, it is assumed that the higher the cost of land the lesser the rate of housing development. Though this might not be the case always, it is worthy of note that it is so in most cases. Taking into consideration the fact that Nigeria is a developing nation and the majority of her population still live below the poverty line, and that all must have a shed over their head, calls for controlled/reduced land cost if housing will ever become affordable to all.

\subsection{Cost Elements Associated to Land}

\subsubsection{Land Registration and Titling}

Awolaja (2015) described land registration as a means by which issues concerning possession 
e-issn: $2229-8568$

or rights in land be penned down and documented (usually with a government agency or department) to make available evidence of title document for easy transaction and avoid unlawful disposal.

In Nigeria, the national land policy stipulates that all land in the custody of each state of federation are unconditionally in the purview of the Military Governor (now State Governor) of that State and that such land shall be held in trust and administered for the use and common benefits of all Nigerians (Land Use Act of 1978). Within the context of the National Land Policy, Section 5(1) 67x empowers the Governor to grant statutory rights of occupancy to any person for all purposes and Section 9(1) has it that it shall be lawful for the Governor when granting a Statutory Right of Occupancy to any person; to issue a Certificate of Occupancy under his hand in evidence of such rights of occupancy if such application is made. Consequently, at the point of issuing Certificates of Occupancy that land registration becomes necessary as a condition to ensure security of individual land rights in a particular way. When the price of land titling is high, it becomes another challenge to housing delivery. Mostly, about thirty five (35) states in the country and entrepreneur goes through eleven (11) processes and hold on for seventy eight (78) days which will still result in paying $15.8 \%$ of the value of property to transfer.

In Ogun state, it takes one (1) year, thirteen (13) steps to follow and $15.6 \%$ price of property assessed to document a property (Doing Business Report, 2014). Unfortunately, the demand for the services rendered by the lands department cannot be said to be inelastic. Hence, the current administration is planning to review upward the statutory charges for the cost of services rendered by the lands department in the state, and this will affect prospective private housing developers in Ogun state. Table 1 shows the statistics of Nigeria and some African countries property registration procedure abstracted from the Doing Business report (2014),

Table 1: Procedures, Time and Cost of Registering property title in Nigeria and some other countries in sub-Saharan Africa

\begin{tabular}{|c|c|c|c|c|}
\hline Country & $\begin{array}{c}\text { Number of } \\
\text { Procedures }\end{array}$ & $\begin{array}{c}\text { Time } \\
\text { (Days) }\end{array}$ & $\begin{array}{c}\text { Cost (\% of } \\
\text { Property Value) }\end{array}$ & $\begin{array}{c}\text { Global Rank in } \\
\text { Registering Property }\end{array}$ \\
\hline Nigeria & 13 & 77 & 20.8 & 185 \\
\hline Gabon & 6 & 103 & 10.5 & 166 \\
\hline Cote d'Ivoire & 6 & 42 & 10.8 & 127 \\
\hline Rwanda & 3 & 12 & 0.2 & 41 \\
\hline Botswana & 4 & 15 & 5.1 & 99 \\
\hline South Africa & 7 & 23 & 6.1 & 105 \\
\hline Egypt & 8 & 63 & 0.7 & 49 \\
\hline Ghana & 5 & 34 & 1.2 & 69 \\
\hline Seychelles & 4 & 33 & 7.0 & 163 \\
\hline Kenya & 9 & 73 & 4.3 & 80 \\
\hline Niger & 4 & 35 & 9.0 & \\
\hline
\end{tabular}

Source: World Bank (2014)

The results on the table above show that Nigeria has the highest number of property registration procedures (13) as well as the highest percentage cost of property registration (20.8) and is ranked one hundred and eighty five (185) higher than her counterparts in the region. The high cost of property registration will no doubt have an effect on the level of housing development in the Nation as a whole.

\subsubsection{Land Taxes}

One of the important avenues for government for revenue is land/property taxes. Revenue from these taxes put land registration system in order and this can be maintained for a good institutional framework for the defense of secured property rights. Land taxes can be classified into (3) three 
e-issn: $2229-8568$

categories: land sales tax (capital profit tax), purchase (registration) tax and usage (real estate) tax. While land sale taxes aim to discourage land price inflation by absorbing land sale profits, purchase (registration) tax and usage (real estate) tax affect mainly the attitude of willing buyers or owners of estate (EEA, 2010). Land/property taxes has been known to be executed in different ways. The familiar ones are the taxes based on land value and the appraised buildings on the land. By implication, buildings at the inner city will generates high revenue from taxes while land at the sub-area or rural areas like agricultural or forest land will generate low income. Land use tax, surface tax and land value tax are other forms of property tax. They are fashioned to regulate land use system. As regards land value tax, it is only charged or levied on the value of the plot of land alone without considering the value of building on it.

\subsubsection{Development Cost}

The evolution of taxation is far back as the pre-Christ era in the world, in which Nigeria is not left out. Prior to independence, the Emirs, Obas and Obis collected various taxes. The tax administers then was the Emirs', Obas' and Obis' agents. With the enactment of the Companies Income Tax Ordinance in 1939, the Federal Board of Inland Revenue (FBIR) came into existence. Since then, taxation in Nigeria has witnessed vigorous changes. This is also applicable to laws of taxation and other body and organ in charge of taxation. Business community changes fast such that there is no space of stagnation in the face of technological developments and this requires more revenue by the government to meet with the running of the country. Table 2 presents an extract summary of the expected spatial impacts of Property tax and development charges from the study of Skaburskis and Tomalty (2000).

Table 2: The Expected Spatial Consequences of Property Taxes and Development Charges

\begin{tabular}{|l|}
\hline \multicolumn{1}{|c|}{ Land Taxes } \\
\hline $\begin{array}{l}\text { 1. Reduce project density as a result of the substitution effect increasing the cost of capital } \\
\text { improvements relative to land. }\end{array}$ \\
\hline $\begin{array}{l}\text { 2. Encourage early redevelopment in the inner city by increasing the carrying cost of } \\
\text { underused land. Delay suburban development. }\end{array}$ \\
\hline 3. Delayed development is at higher densities. \\
\hline $\begin{array}{l}\text { 4. Encourage fiscal zoning that favors lower density residential projects and leads to the } \\
\text { over-supply of non-residential land. }\end{array}$ \\
\hline \multicolumn{1}{|c|}{ Development Cost Charges } \\
\hline 1. Reduce project density when schedules do not reflect lot sizes. \\
\hline 2. Delay development and led to higher densities. \\
\hline $\begin{array}{l}\text { 3. Streamline the development process, reduce uncertainty. Ensure that infrastructure is } \\
\text { provided on time. }\end{array}$ \\
\hline 4. Reduce public resistance to higher density projects. \\
\hline
\end{tabular}

Source: Skaburskis and Tomalty (2000)

\subsubsection{Cost of settling local chief(s) and 'Area boys' (touts)}

In the past, this practice was strange to the society particularly in the Nigerian culture. However, today it seems to have taken the centre stage. This is a situation where money is paid to the local chief on every land purchased within his domain. The money is made compulsory and the fee is usually fixed by the chief (though sometimes negotiable). This issue has become alarming to individuals improving their land. It has over the years distort peace development in some part of African cities. In the year 2018, Lagos and Ogun state governments introduced some measures in curbing the activities of the so called "Omo Onile" (Area boys) in the form of introduction of the task force and the enforcement of the law. In spite of achieving success to some extent, the task force still faces a formidable challenge. Private individuals who wish to make developments often struggle to meet up these extra costs imposed on them by the community heads. The effect often reflects in delay in project commencement as reduced quality of construction or a total alteration of the intended design. 
Practically in all city centres in "Awori" kingdom ranging from Sango, Ota, Iju, Onibukun, Igbesa, Agbara, etc. have touts that bother and cause chaos on any one that purchases land within their domain. In these towns, one cannot start a new development or even carry out some major renovations unless the owners paying some certain fees to the youth association. If one fails to oblige, they distort and cart away the artisan tools and some building materials. Despite a land prohibition of fraudulent practices on land and property law, 2012, they still move around in developing sites to cause havoc. This action of the youth could be disturbing and it increases the cost attached to land incurred by the purchaser which in turn discourages private residential developers from building.

\subsection{Private Sector Involvement in Housing}

Structural variations in housing markets can be linked to differences in private consumption pattern, house price dynamics across EU countries. For instance, changes of house prices in Germany over the last couple decades were assumed to be connected to supply factors, where more responsive residential investments may support the smooth function of price quality mechanism compared to other EU countries. According to the World Bank, Doing Business's (2011) report, business regulation across world economics support this intuition. In EU ranking for example, Germany represents one of the countries with a lower average number of 100 days required to get with an average of 257 days.

In Nigeria, private sector provides the stock for the housing market. The importance and relevance of the private sector in housing provision has been documented in the National Housing Policy (2004). Despite this, it is worthy to note that there are various factors that affect private developers in housing delivery system in Nigeria which is a combination of many integrated legal components which include;

1. Government policies

2. Cost of land registration

3. Transferability of existing title documents

4. Documentation cost; etc.

In 2002, it is well known that both the formal and informal private sectors have immensely contributed to providing over $90 \%$ of the housing in the country (FGN, 2002). Olatubara, (2007) affirms to this by making it known that private sector's contribution is about $80 \%$ to the total supply of housing. Although, it was observed that the houses provided by private sector are not easily affordable by lowincome family. This has prompted the government's involvement into housing market. It is pertinent to note that housing market include two (2) basic activities; the production and allocation housing units. The production unit involves both the public and private sector, while the allocation process in the two sectors vary vividly. Accessibility and allocation of housing unit is through the public sector (government). On the other hand, accessibility of housing units offered by private sector lies solely on the price system through the interaction of demand and supply. As such, it is easy to assume that on the private sector, housing market is determined by the price, invariably, low-income earners will be automatically excluded. The vital elements that not been considered private sector initiatives are affordability, end user-driven and value management. The private sector has not contributed much in providing housing that are affordable to the low- income earners.

\subsection{STUDY AREA}

The study areas are Ota, Iju, Atan and Agbara of Ado-Odo Ota local government area of Ogun State Nigeria. Ado-Odo/Ota Local Government can be referred to as the "Local Government of Distinction". It is an economically developing Local Government that has one of the largest concentrations of industries; particularly the manufacturing ones and assembly plants abound in the area. These industries are located at Ota, Agbara and Sango- Ota, all under Ado-Odo/Ota Local Government. A city like Ota, Atan, Agbara and Sango are economically developing towns that has one of the largest concentrations of industries; particularly the manufacturing ones and assembly plants. It also has tertiary institutions (two private universities and a private polytechnic). Despite this, Ota has only one housing 
e-issn: $2229-8568$

estate built by the government. Most of the property developments have been on individual bases.

\subsection{METHODOLOGY}

A quantitative approach was adopted in this study. Questionnaires were administered with the estate surveyors and valuers in the study areas and the government officials at the Ogun State Bureau of Land. Forty-two (42) questionnaires were distributed to the estate surveyors and valuers and thirtyfour (34) to the government officials. The purpose of the questionnaire survey was to obtain requisite information on personal information of the respondents, average cost of land registration, land cost elements, trend of land cost in Awori land, importance of land cost elements, number of houses developed, frequency of house development and factors affecting private housing development.

The data obtained from the respondents were analysed with the use of Statistical Package for Social Science (SPSS), version 17.

\subsection{RESULT AND ANALYSIS}

The forty two (42) questionnaires were distributed to estate surveyors whom are also into property development and have vast professional knowledge on value and appraisal of land in the study area, out of which twenty one (21) were retrieved and used for the analysis, representing $50 \%$ response rate. Meanwhile, thirty four (34) questionnaires were administered to officers at the bureau of land and survey in different units relevant for the study and all were returned representing $100 \%$ response rate. Thus, the response rates of both categories of respondents are adequate for the study.

Table 3: Response rate from respondents

\begin{tabular}{lcccc}
\hline & \multicolumn{2}{c}{ Estate surveyor/developers } & \multicolumn{2}{c}{ Land Bureau officers } \\
\cline { 2 - 5 } & $\mathrm{N}$ & $\%$ & $\mathrm{~N}$ & $\%$ \\
\hline Total administered & 42 & 100 & 34 & 100 \\
Total used for the analysis & 21 & 49.0 & 34 & 100 \\
\hline
\end{tabular}

\subsection{General Information of Respondents' - Estate Surveyors/Developers and Land Bureau Officers}

This section presents the general information of respondents such as level of education, area of specialization, professional affiliation, grade of membership and working experience.

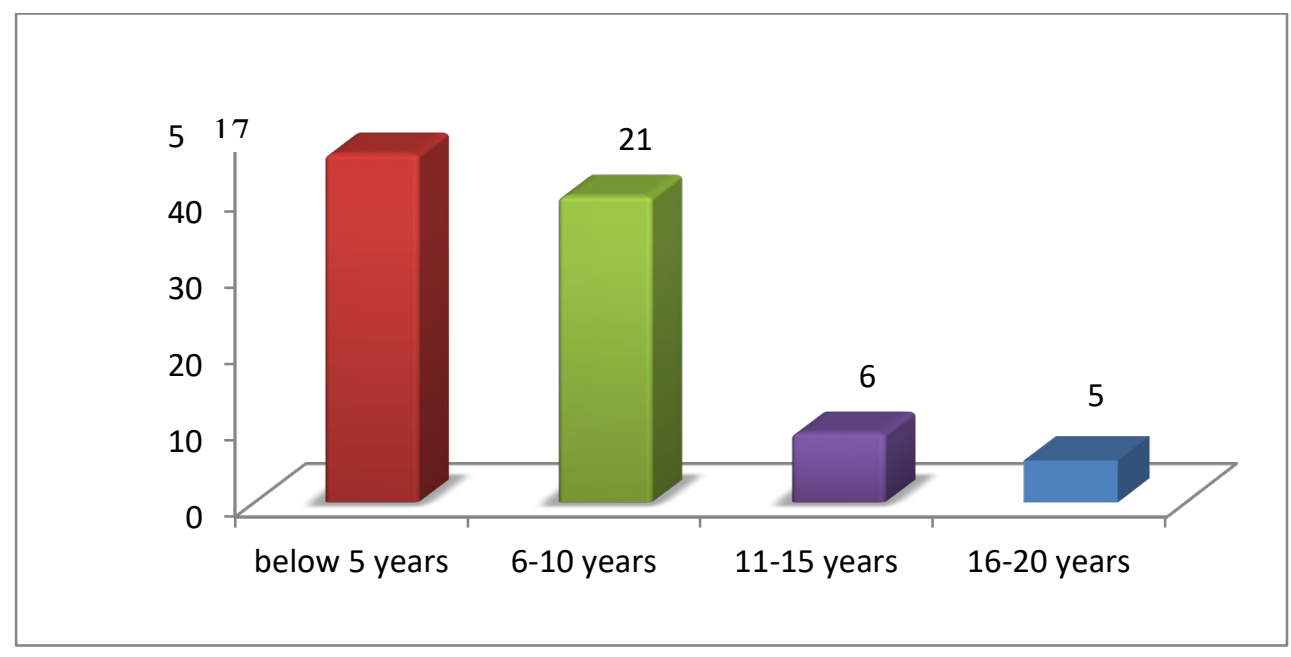

Figure 2: Working experience of respondents 
e-issn: $2229-8568$

Figure 2 depicts the working experience of the respondent estate surveyors. The chart shows that $45.5 \%$ have a working experience of below 5 years, $40 \%$ have working experience of $6-10$ years. On the other hand, $9.1 \%$ have worked for $11-15$ years and the rest $(5.5 \%)$ have working experience of 16-20 years. Therefore, since a cumulative of $54.6 \%$ have been in practice above 5 years, it could be safely inferred that they would be able to address the subject matter succinctly. Table 4 and Table 5 show the areas of specialisation of the estate surveyors/developers and the response rates from the Land Bureau Officers.

Table 4: Areas of specialisation of respondents

\begin{tabular}{lll}
\hline Specialisation & Specialised & Rank \\
\hline Property management & 79.3 & 1 \\
Agency & 77.0 & 2 \\
Development & 73.6 & 3 \\
Valuation & 67.8 & 4 \\
Project management & 47.1 & 5 \\
Appraisal & 44.8 & 6 \\
Investment analysis & 8.0 & 7 \\
\hline
\end{tabular}

Many of the respondents are investment analyst, followed by property manager and estate agents and property developers. With this, there responses will be explicit in taking a fair decision on evaluating the cost elements involved in land acquisition.

Table 5: Questionnaire distribution and Retrieval Rate at Ogun State Bureau of Lands and Survey.

\begin{tabular}{|c|c|c|c|}
\hline Units/ Departments & Number of Staff & Response Level & \% of Response \\
\hline Land services & 10 & 10 & 100 \\
\hline Land Management & 8 & 8 & 100 \\
\hline Ratification & 8 & 8 & 100 \\
\hline Survey & 5 & 5 & 100 \\
\hline Finance and Account & 3 & 3 & 100 \\
\hline Total & $\mathbf{3 4}$ & $\mathbf{3 4}$ & $\mathbf{1 0 0}$ \\
\hline
\end{tabular}

Source: Author's field survey, 2021.

\subsection{Land Cost Elements}

This section examines the available land cost elements within the state and the important land cost elements.

Table 6 below presents the available land cost elements from the information and data collected from the government officials at the Ogun state Bureau of Land and Survey. The table shows that all the land cost elements are available. However, land registration, lease, deed of assignment, transfer of attorney, titling, consent fees and sublease are the most predominant, while charting fees, development fees, search, endorsement fee and property tax are rarely available.

Table 6: Land cost elements identified at the Bureau of Land and Survey

\begin{tabular}{lll}
\hline Cost elements & Percentage & Rank \\
\hline Land registration & 98.9 & 1 \\
Lease & 98.9 & 2 \\
Deed of assignment & 97.8 & 3 \\
Transfer of attorney & 97.8 & 3 \\
Titling & 95.5 & 5
\end{tabular}


Consent fees

Sub lease

Stamp duties

Certified true copy

Survey plan

Charting fees

Development fees

Search

Endorsement fees

Property tax

Probate
95.5

95.5

93.3

93.3

92.0

86.5

84.3

84.1

78.7

71.6

40.9
5

5

8

8

10

11

12

13

14

15

16

Table 7: Pearson correlation analysis for land cost elements and rate of housing developments.

\begin{tabular}{lc}
\hline Correlation coefficient & 0.374 \\
Level of significant & 0.004 \\
$\mathrm{~N}$ & 59 \\
\hline
\end{tabular}

Table 7 shows that there is a significant relationship between land cost elements and rate of housing developments at $95 \%$ level of significance since $p<0.05$. The positive correlation implies that land cost elements and rate of housing developments are moving in the same direction which suggests that an increase in one will affect the other.

Table 8: Legal factors affecting housing developments

\begin{tabular}{lrl}
\hline Legal factors & Mean score & Rank \\
\hline Documentation cost & 4.57 & 1 \\
Cost of land registration & 4.36 & 2 \\
Cost of settling the local chiefs or Area boys & 4.26 & 3 \\
Transferability of existing title & 4.05 & 4 \\
Reliability of title document & 3.94 & 5 \\
\hline
\end{tabular}

Table 8 shows the legal factors that affect housing development in the study area. From the table, documentation cost has the highest impact on housing development followed by the cost of land registration, the cost of settling the local chiefs, transferability of existing title and reliability of title document.

\subsection{SUMMARY OF FINDINGS}

Land cost elements represent one of the most significant components of the cost of new housing. Land acquisition comes with certain cost elements such as land registration and titling, development fees, property/land tax, legal fees, survey fees and stamp duties amongst others. Hence, this study examined the effect of land cost elements on private housing development in "Awori Land", Ogun state, using Ota, Iju Atan and Agbara as a case study State. The study discovered that the average costs of land registration is predominantly between N49, 000-N115, 000. In addition, Bureau of Lands and Survey in Ogun State submitted that land charges do not have a fixed duration for review as the revision is done as deemed fit. With regard to the duration for land registration, a very significant proportion $(82.5 \%)$ of the land bureau officer agreed that land registration takes place above one (1) year. The rest indicated otherwise; hence, there is the need for security of rights by developers which have cost implications. 
e-issn: $2229-8568$

It is also revealed in the study that majority of the land cost elements i.e. land registration, transfer of power attorney, lease, survey plan for CTC of deed, deed of assignment amongst others were rated as important with mean scores of above 4 . The only land cost element accorded the least mean i.e. 3.67 is probate. All these have effect on the possession and transfer on real estate. This is supported by Manganelli, (2020) who opined that financial analysis of real estate is constructed and stimulated in other to understand what type of taxation investment is more sensitive.

With regard to the type of private housing developed in the study areas, the study found that tenement building is mostly developed, followed by block of flats, bungalow, semi-detached and detached houses. On the contrary, high-rise, maisonette and terrace building is rarely constructed.

Furthermore, the regression analysis of the effect of land cost elements on rate of private housing development in the study area revealed that land cost element is significant (at $5 \%$ level of significance, $\mathrm{t}=3.042$ ) suggesting that land cost elements have positive impact on housing development. In addition, Pearson correlation analysis at 95\% level of significance further established that land cost elements have significant relationship with rate of housing developments, $p<0.05$. Lastly, Pearson Correlation analysis for land cost elements and type of housing developments revealed a significant relationship at $95 \%$ level of confidence $(p<0.05)$. This implies that land cost elements determine the type of housing developments. Hence, the alternative hypothesis that there is a significant relationship between land cost elements and type of private housing developments is accepted.

\subsection{CONCLUSION AND RECOMMENDATION}

The findings of this study revealed that land registration cost, lease cost, deeds of assignment were ranked as important. It is also found that there is also a significant relationship between land cost elements and rate of housing development. A significant relationship is also found between land cost elements and the types of housing development. The study further revealed that there is a positive relationship between the land cost elements and the rate of housing development

As findings imply that an increase in one of the land cost elements will affect housing development, the government of Ogun state should undertake the following initiatives. The government should stimulate land title registration interest. A greater commitment by the government will be through the adoption and maintenance of information technology solutions to land information management problems. Also, there is a need to reduce the level of bureaucracy associated with titling/registration process thereby quickening land acquisition. It is necessary to reduce the chain of schedule in formal land acquisition. This will go a long way to facilitate efficient residential property development in the study area. It is also recommended that the Government of Ogun State should develop land registration blueprint to guide individual land owners on the procedures of land registration in the state as the present procedure is unclear.

\subsection{REFERENCES}

1. Awolaja, A.G (2015): Emerging global best practice in urban regeneration: Implication for Estate Surveyors and Valuers. A paper submitted to African Real Estate Society III, (AFRES).

2. Collateral Management. Retrieved from http://www.collateralmanagement.org

3. Douglas, D.J.T (2014): Upland Use predicts population decline in a globally near threatened wader. Journal of Applied Ecology, 51(1), 194-203.

4. EEA Technical Report (2010). Retrieved from https://www.eea.europe.eu.

5. Essaghah, A., Ighoruemufua, H.O., Ogedengbe, O.K (2004): Formulating a Good Urban Land 
e-issn: $2229-8568$

Policy for Nigeria. J Hum.Ecol, 15(2).

6. Institute of Cost and Work Accountants (ICWA) 2020.

7. Manganelli, A. (2020): Realizing local food policies: a comparison between Toronto and the Brussels-Capital Region's stories through the lenses of reflexivity and co-learning. Journal of Environmental Policy \& Planning. 22 (3) 366-380.

8. Nichols, J, Oliner,S.D and Mulhall, M.R (2010):Commercial and Residential Land Prices Across the United States. FEDs Working Paper NO.16.

9. Ogedengbe, P.S (2004): Formulating a good urban and land policy for Nigeria. Journal of Humanities, 15(2) 92.

10. Olatubara, C.O (2007): Private sector Driven Housing in Nigeria: Issues, Constraints, Challenges and Prospects. In Timothy Olugbenga Nubi, Modupe Moronke Omirin \& Akintade Samuel Afolayan eds. Private sector Driven Housing in Nigeria: Issues, Constraints, Challenges and Prospects: Department of Estate Management, University of Lagos.

11. Omatsone, O \& Okoye, S (2013). Factors affecting Physical Development of Residential layouts in Asaba metropolitan Region of Delta State, Nigeria. Journal of Art and Design Studies, 15, 6-15.

12. Ong, T. S (2013). Factors affecting the price of housing in Malaysia. Journal of Emerging Issues in Economics, Finance and Banking, 1 (5), 414 - 429.

13. Skaburskis and Tomalty (2000). The effect of property taxes and development cost charges on urban development: Perspective of planners, Developers and Finance officers in Toronto \&Ottawa. Canadian Journal of Regional Science. 23(2).

14. Stephen, D .O, Nicolas, J \& Mulhall, M.R (2010). Commercial and Residential Land Prices across the United States. FEDS working paper, NO.16.

15. Uwem, I.E (2014): Indigenous Land Management Practices and Land Cover Change in Akwa Ibom State, Nigeria. Journal of Environmental Protection, 05(16): 1541-1552.

16. World Bank Annual Report, 2014, Washington DC.

17. World Bank Annual Report in Doing Business, 2011. 